\title{
39. GEOLIPID COMPARISON OF BIOGENIC SEDIMENTS FROM DEEP SEA DRILLING PROJECT HOLES 530B, ANGOLA BASIN, AND 532, WALVIS RIDGE ${ }^{1}$
}

\author{
Philip A. Meyers and Keith W. Dunham, Oceanography Program, Department of Atmospheric and Oceanic \\ Science, The University of Michigan, Ann Arbor, Michigan
}

\begin{abstract}
Distributions of free and bound $n$-alkanes, $n$-alkanoic acids, and $n$-alkanols were determined in order to compare the character of organic matter contained in organic-carbon-rich sediments from two sites sampled by the hydraulic piston corer. Two diatomaceous debris-flow samples of Pleistocene age were obtained from Hole 530B in the Angola Basin. A sample of bioturbated Pleistocene diatomaceous clay and another of bioturbated late Miocene nannofossil clay were collected from Hole 532 on the Walvis Ridge. Geolipid distributions of all samples contain large terrigenous contributions and lesser amounts of marine components. Similarities in organic matter contents of Hole 530B and Hole 532 sediments suggest that a common depositional setting, probably on the Walvis Ridge, was the original source of these sediments through Quaternary, and possibly late Neogene, times and that downslope relocation of these biogenic deposits has frequently occurred.
\end{abstract}

\section{INTRODUCTION}

Most deep-sea sediments contain less than $0.2 \%$ organic carbon (Degens and Mopper, 1976), suggesting that the circumstances favoring accumulation and preservation of organic matter in the ocean bottom rarely occur. However, factors such as high rates of primary production, enhanced sinking rates of detritus, an expanded oxygen minimum zone, and high sedimentation rates, all of which are found in upwelling areas, can combine to allow large concentrations of organic matter to accumulate in oceanic sediments. Such organic material represents the residue of organisms formed by biosynthesis in the photic zone of the highly productive overlying waters, augmented by land-derived biological detritus transported to ocean basins by water movement and winds.

Upwelling systems provide optimized situations for the investigation of organic matter inputs to sediments because underlying sediments contain sufficiently high concentrations of biogenic matter to permit detailed analyses of temporal fluctuations in input rates and character. It is evident, however, that even under upwelling areas, such as the Benguela Current system offshore of southwest Africa, the appearance of the circumstances favoring organic matter accumulation is episodic.

Several locations under the offshore edge of the Benquela Current have been sampled as part of the Deep Sea Drilling Project/International Phase of Ocean Drilling (DSDP/IPOD). Erdman and Schorno (1978) report organic carbon concentrations as high as $7.2 \%$ in upper sections of sediments obtained from Site 362 by rotary drilling during DSDP Leg 40. Based upon concentration patterns of organic carbon, diatom abundances, and nutrient incorporation in these sediments, a late

\footnotetext{
${ }^{1}$ Hay, W. W., Sibuet, J.-C., et al., Init. Repts. DSDP, 75: Washington (U.S. Govt. Printing Office).
}

Miocene onset of upwelling has been proposed by Diester-Haass and Schrader (1979) and Seisser (1980). Shipboard organic carbon data from Sites 530 and 532 corroborate with those from Site 362 (Hay et al., 1982; Meyers, Brassell, and Huc, this volume).

Sediments from Hole 530B in the Angola Basin consist of turbidites and debris-flow deposits, presumably originating from biogenic oozes originally laid down on the Walvis Ridge. The sediments at Site 532 on the Walvis Ridge are made up of alternating sequences of light and dark pelagic oozes and are heavily bioturbated. The dark layers are richer in organic carbon, clay and pyrite (Hay et al., 1982). A possible explanation for this pattern is episodic increases in wind-driven marine productivity, creating relative increases in organic matter inputs and sedimentation rates. The increased clay component of the dark layers may be the result of an increased eolian input of continental material.

Based upon general similarities in microfossils, sediment texture, and organic matter character, Hay et al. (1982) concluded that Miocene and younger sediments at Site 530 in the Angola Basin represent relocated material which was originally deposited on the Walvis Ridge. Meyers, Brassell, and Huc (this volume) give concentrations of organic carbon and $\mathrm{C} / \mathrm{N}$ ratios of organic matter of Neogene and Quaternary samples from Sites 530 and 532. The values are quite similar in both the turbiditic and debris-flow samples from Hole 530B and in the bioturbated oozes from Hole 532, agreeing with the lithologic similarities described by Hay et al. (1982).

This chapter gives further comparisons of the organic matter content of sediments from Holes 530B and 532. Distributions of extractable and bound $n$-alkanes, $n$-alkanoic acids, and $n$-alkanols are examined as indicators of sources and preservation of organic matter.

\section{METHODS}

Biogenic sediments were obtained by continuous hydraulic piston coring, a procedure which minimizes sediment disturbance, at DSDP Sites 530 and 532 (Fig. 1). Samples were selected shortly after core sec- 


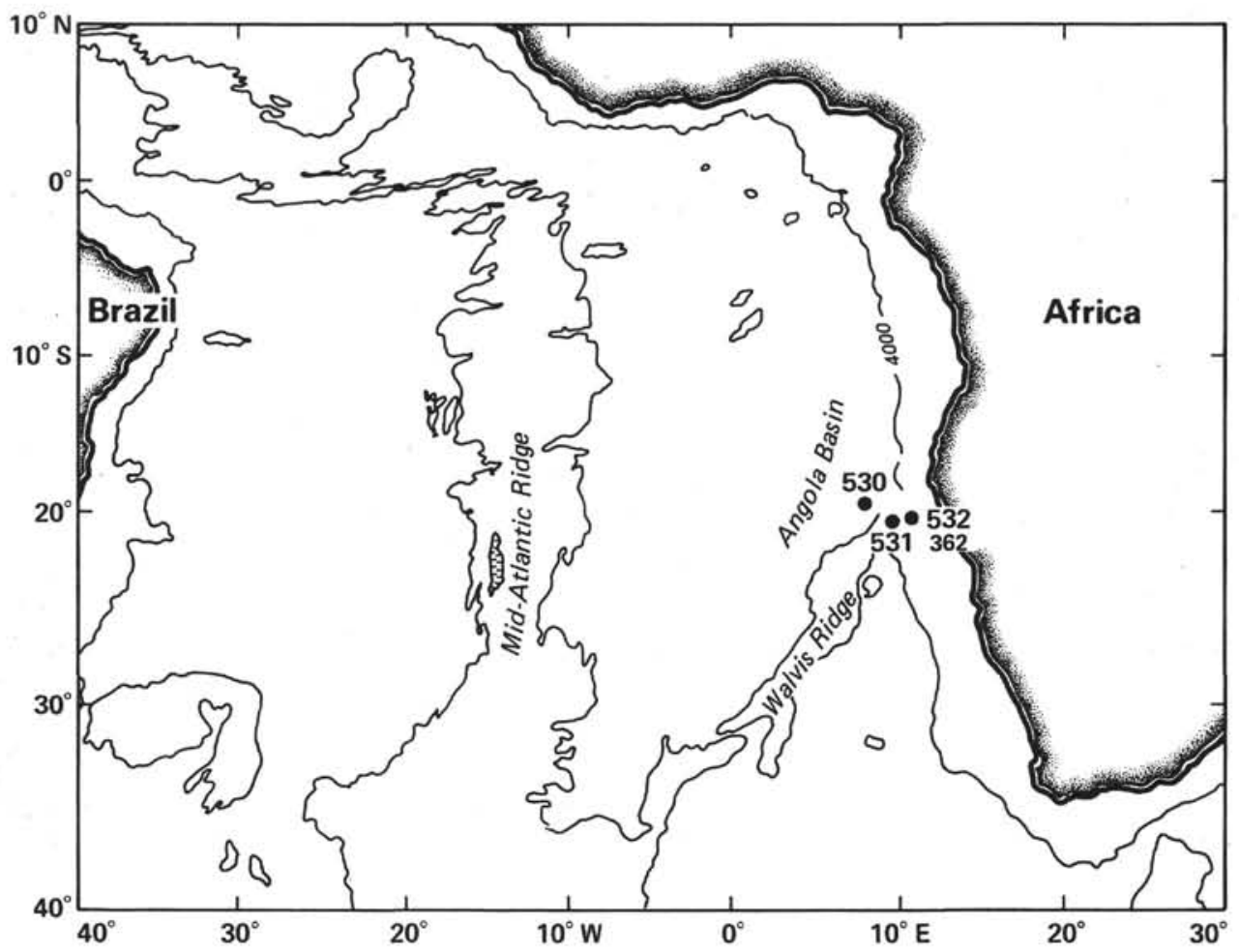

Figure 1. Locations of Site 530 in the Angola Basin and Site 532 on the Walvis Ridge which were sampled by hydraulic piston coring during DSDP Leg 75 . Site 532 is about $1 \mathrm{~km}$ downslope from Site 362, which was sampled by rotary drilling during DSDP Leg 40 . (Bathymetric contours given in $\mathrm{m}$.)

tions were opened on board D/V Glomar Challenger and frozen immediately in Kapak bags for storage. The samples were subsequently freeze-dried in preparation for shore-based analysis.

Two Pleistocene samples from Hole 530B in the Angola Basin (water depth $4639 \mathrm{~m}$ ) and one Pleistocene sample from Hole 532 on the Walvis Ridge (water depth $1341 \mathrm{~m}$ ) were chosen for comparison. In addition, a late Miocene sample (Sample 532-58-2, 80-90 cm) was selected for contrast. General descriptions of these samples and their organic matter contents are given in Table 1.

A two-stage extraction procedure was used to obtain the geolipid contents of the freeze-dried samples. Soxhlet extraction with toluene/ methanol yielded the easily extracted, unbound fraction of geolipids. A second extraction with $0.5 \mathrm{~N} \mathrm{KOH}$ in methanol/toluene provided the hydrolyzable and bound components. Both fractions were treated with methanolic boron trifluroide to convert fatty acids to their methyl esters, and then geolipid subfractions were separated by column chromatography on alumina over silica gel. The subfractions so obtained were alkanes, fatty acid methyl esters, and hydroxy lipids. The hydroxy subfraction was silylated with BSTFA prior to gas chromatography.
Splitless injection gas-liquid chromatography was employed to characterize the geolipid subfractions. A Hewlett-Packard 5880 FID gas chromatograph equipped with a $20 \mathrm{~m}$ SE54 fused silica capillary column was used with hydrogen as carrier gas. Individual compounds were tentatively identified by retention times in this preliminary qualitative survey. Data have been corrected for laboratory contaminants and for mass discrimination over the wide molecular-weight ranges surveyed.

\section{RESULTS AND DISCUSSION}

\section{General}

The Pleistocene samples listed in Table 1 are rich in diatom remains and have concentrations of organic carbon substantially higher than the mean of $0.2 \%$ given for modern deep-ocean sediments by Degens and Mopper (1976). Abundant concentrations of biogenic opal and organic carbon are two of the important indicators

Table 1. General descriptions and organic contents of hydraulic piston core samples, from DSDP Leg 75. ${ }^{\mathrm{a}}$

\begin{tabular}{|c|c|c|c|c|c|c|c|}
\hline $\begin{array}{c}\text { Sample } \\
\text { (interval in } \mathrm{cm} \text { ) }\end{array}$ & $\begin{array}{c}\text { Water } \\
\text { depth (m) }\end{array}$ & $\begin{array}{l}\text { Sub-bottom } \\
\text { depth }(m)\end{array}$ & Age & $\begin{array}{c}\text { Sediment } \\
\text { description }\end{array}$ & $\mathrm{CaCO}_{3}(\%)$ & $\mathrm{C}_{\text {org }}(\%)$ & Atomic $\mathrm{C} / \mathrm{N}$ \\
\hline \multicolumn{8}{|l|}{ Angola Basin } \\
\hline $530 \mathrm{~B}-4-1,75-80$ & 4629 & 12 & Pleistocene & $\begin{array}{l}\text { Debris flow diatom- } \\
\text { nannofossil ooze }\end{array}$ & 6 & 2.7 & 15.6 \\
\hline $530 \mathrm{~B}-9-2,110-120$ & 4629 & 35 & Pleistocene & $\begin{array}{l}\text { Debris flow diatom- } \\
\text { nannofossil ooze }\end{array}$ & 15 & 1.8 & 7.8 \\
\hline \multicolumn{8}{|l|}{ Walvis Ridge } \\
\hline $532-5-2,100-110$ & 1331 & 20 & Pleistocene & $\begin{array}{l}\text { Bioturbated dark-olive } \\
\text { diatom clay }\end{array}$ & 4 & 9.7 & 26.3 \\
\hline $532-58-2,80-90$ & 1331 & 237 & late Miocene & $\begin{array}{l}\text { Bioturbated dark-olive } \\
\text { nannofossil clay }\end{array}$ & 44 & 2.1 & 16.1 \\
\hline
\end{tabular}

${ }^{a}$ From Meyers, Brassell, and Huc (this volume). 
of high productivity resulting from upwelling that are listed by Diester-Haass (1978). The late Miocene sample, although also rich in organic carbon, contains less opal and may represent an earlier stage in the development of the upwelling flora in this part of the eastern South Atlantic Ocean. All four of these Leg 75 samples contain more opal and have much greater amounts of organic carbon than do Pleistocene-through-Miocene samples from DSDP Sites 525 and 528 on the Walvis Ridge (Meyers and Keswani, in press). These Leg 74 sites are about $1000 \mathrm{~km}$ seaward of the Leg 75 locations, and their sediments accumulated under open-ocean areas having low surface productivity but in water depths 1 to $2 \mathrm{~km}$ shallower than at Site 530 in the Angola Basin. Suess (1980) has noted that the flux of organic matter to the deep sea continually decreases with increasing depth, and so the relatively high values of organic carbon in the Angola Basin samples are exceptional.

Atomic $\mathrm{C} / \mathrm{N}$ ratios of the four samples in Table 1 are within the range reported for young marine sediments (Müller, 1977) but are higher than values found in organic-carbon-lean samples of similar ages from DSDP Legs 58 (Waples and Sloan, 1980), 72 (Meyers and Dunham, in press), and 74 (Meyers and Keswani, in press). The ratios in Table 1 are typical of marine-derived organic matter (Müller, 1977). Although the deeper sample of each pair of samples from both locations has a lower $\mathrm{C} / \mathrm{N}$ ratio than its shallower counterpart, the full set of $\mathrm{C} / \mathrm{N}$ data given by Meyers, Brassell, and Huc (this volume) shows no depth-related change in these ratios in sediments younger than middle Miocene. The effects of diagenesis in lowering $\mathrm{C} / \mathrm{N}$ ratios, documented by Waples and Sloan (1980) in organic-carbon-lean sediments from DSDP Leg 58, evidently is concealed in sediments richer in organic matter.

\section{Alkanes}

Distributions of both free and bound $n$-alkanes in Pleistocene samples from the Angola Basin (Hole 530B) and in Pleistocene and Miocene samples from the Walvis Ridge (Hole 532) are dominated by odd-carbon, long-chain components (Fig. 2). Land plants commonly have hydrocarbon compositions dominated by $\mathrm{C27}$, $\mathrm{C} 29$, and C31 $n$-alkanes, whereas algae contain mostly shorter-chain components in the $\mathrm{C} 16$ to $\mathrm{C} 20$ range (Simoneit, 1978a). Quaternary sediments containing terrigenous hydrocarbon distributions like those at these locations have been reported at other DSDP sites. Some examples include Sites 436 and 440 in the Japan Trench (Brassell et al., 1980; Rullkötter et al., 1980a), Sites 467, 469 , and 471 offshore at southern California (Rullkötter et al., 1981; McEvoy et al., 1981; Simoneit and Mazurek, 1981), and Sites 487 and 491 in the Middle America Trench (Brassell et al., 1981). The dominant $n$-alkane in these examples is $n$-C29, but it is $n$-C31 in Quaternary samples from Site 362 on the Walvis Ridge (Boon et al., 1978), Sites 442, 443, and 444 from northern Philippine Sea (Rullkötter et al., 1980b), and Sites 515 and 517 in the western South Atlantic (Meyers and Dunham, in press).
Downslope transport of organic matter derived from the African continent north of the Walvis Ridge may contribute to the hydrocarbon distributions found in the Angola Basin, but it is unlikely that the Namibia coastal areas provide much land-plant matter because of their desert conditions. Hence, downslope transport is not likely to be important in bringing land-derived material to the Walvis Ridge sediments at Site 532. A more likely transport process of terrigenous hydrocarbons to this location is by eolian dusts. Simoneit (1977) reports that terrigenous components dominate the lipid character of dust particles collected over the Atlantic Ocean. Because $n$-C31 dominates $n$-alkane distributions at Sites 530 and 532, eolian input may be important to the hydrocarbon contents of sediments deposited at both these South Atlantic locations.

Chromatograms of the free hydrocarbon fractions of all four samples contain an unresolved complex mixture (UCM) peaking around $n$-C20 while those of the bound fractions exhibit no UCM. None of the UCMs constitute more than half of the hydrocarbon fraction, and none of the hydrocarbon chromatograms resemble those of potential shipboard contaminants (cf. Doran and Johnson, 1979). It is probable the UCMs arise from microbial or possibly diagenetic processes rather than from contamination.

Pristane/phytane ratios in Table 2 are one or greater in the free hydrocarbon subfractions of three of the four samples. Such values indicate organic matter accumulation under aerobic bottom waters (Didyk et al., 1978). The values of less than one in the free hydrocarbons of Samples 530B-4-1, 75-80 cm, and in all of the bound hydrocarbons, suggest deposition under anoxic conditions, and such conditions may occur as an intensified midwater oxygen minimum zone in this part of the South Atlantic. Microbial contributions of hydrocarbons are indicated by low pristane $/ n-\mathrm{C} 17$ values in all of the Angola Basin subfractions and in the bound hydrocarbons in the Walvis Ridge samples. Because low pristane/ $n-\mathrm{C} 17$ and pristane/phytane ratios are found together, microbial activity may be responsible for both ratios, as well as for the UCMs seen in the free hydrocarbon subfractions.
Alkanoic Acids
Distributions of $n$-alkanoic acids from Pleistocene Sections 530B-4-1, 530B-9-2, and 532-5-2 are compared in Figure 3. All have strong even-to-odd carbon number predominances (Table 2) typical of biogenic acids. The free n-acids have bimodal distributions with maxima at $n-\mathrm{C} 16$ and $n-\mathrm{C} 26$, whereas the bound acid fractions are dominated by $n-\mathrm{C} 16$ and have only small contributions of longer chain-length acids. Similar differences be- tween distributions of free and bound $n$-alkanoic acids have been described in samples of Pleistocene diatoma- ceous clays from DSDP Site 440 in the Japan Trench (Brassell et al., 1980).
Because the free acid subfraction constitutes the ma- jor fraction of the total acids in DSDP samples (Brassell et al., 1980; Meyers, Trull, and Kawka, this volume) and 

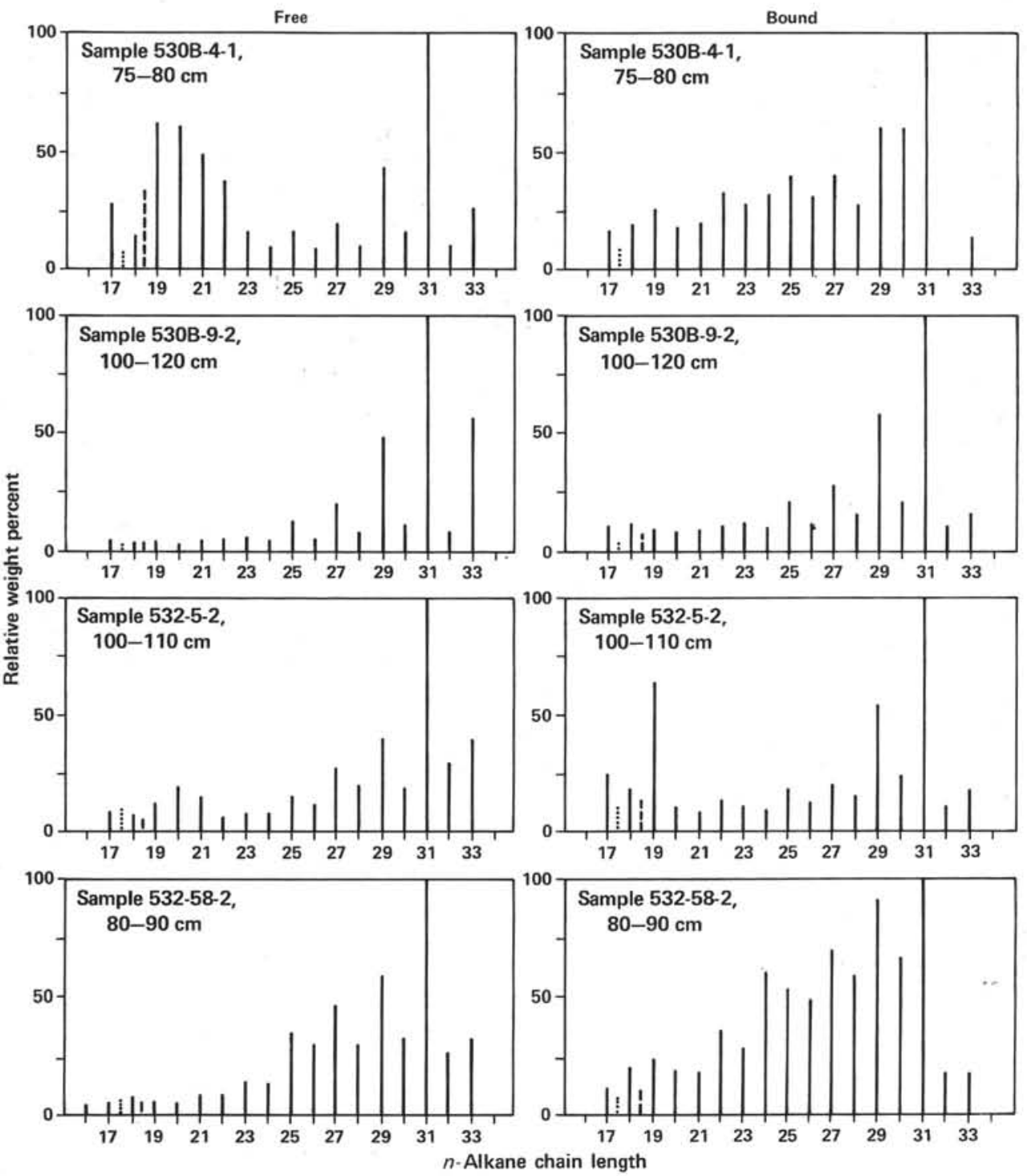

Figure 2. Histograms of free (left) and bound (right) $n$-alkanes normalized to the major component in each distribution (100\%). Sample 532-58-2, $80-90 \mathrm{~cm}$ is late Miocene; the others are Pleistocene. Pristane and phytane represented by dotted and dashed lines, respectively.

because the extraction procedure used to obtain free acid subfractions and the procedures employed by other investigators to obtain total acids are similar, distributions of free acids of these Leg 75 samples can be compared with total acid distributions from other DSDP samples. In general, $n$-alkanoic acid distributions present in Quaternary sediments from ocean margin areas are similar to the free acid distributions shown in Figure 3. Examples of similar distributions are found in Pleistocene and Pliocene sediments from Site 362 on the Walvis Ridge (Boon et al., 1978), a Pleistocene sample from Site 364 in the Angola Basin (Simoneit, 1978), Quaternary diatomaceous clays from the California Borderland (Simoneit and Mazurek, 1981), and Quaternary sediments from the Middle America Trench (Brassell et al., 1981). In these distributions, the prominence of $\mathrm{C} 24, \mathrm{C} 26$, and C28 n-acids indicates important contributions of land-plant acids (cf. Simoneit, 1978a). The widespread occurrence of $n$-C16 and $n$-C18 acids in terrigenous plants, marine algae, and bacteria makes them useful as evidence of biological origin but not as specific source indicators. The relative abundances of $n$-C14 in the free and bound distributions in Figure 3 suggest algal or bacterial inputs (Simoneit, 1978; Brassell et al., 1981). In addition, wax esters believed to originate from diatoms have been described in modern Namibian shelf sediments (Boon and deLeeuw, 1979) and may contribute to the important amounts of C14, C16, and C18 nalkanoic acids in the Leg 75 samples.

In contrast to the distributions of fatty acids found in the Quaternary sediments from near the African and other continental margins, few long-chain, terrigenous $n$-acids are present in organic-carbon-lean sediments from the Brazil Basin and Rio Grande Rise (Meyers and Dunham, in press) or from Leg 74 sites on the Walvis Ridge (Meyers and Keswani, in press). Their absence 
Table 2. Ratios of geolipid components extracted from hydraulic piston core samples from DSDP Leg 75.

\begin{tabular}{|c|c|c|c|c|c|c|c|c|}
\hline \multirow{3}{*}{$\begin{array}{l}\text { Geolipid } \\
\text { fraction }\end{array}$} & \multicolumn{4}{|c|}{$\begin{array}{c}\text { Sample } \\
\text { (interval in } \mathrm{cm} \text { ) }\end{array}$} & & & & \\
\hline & \multicolumn{2}{|c|}{$\begin{array}{c}530 \mathrm{~B}-4-1 \\
75-80\end{array}$} & \multicolumn{2}{|c|}{$\begin{array}{c}530 \mathrm{~B}-9-2 \\
110-120\end{array}$} & \multicolumn{2}{|c|}{$\begin{array}{l}532-5-2 \\
100-110\end{array}$} & \multicolumn{2}{|c|}{$\begin{array}{c}532-58-2 \\
80-90\end{array}$} \\
\hline & Free & Bound & Free & Bound & Free & Bound & Free & Bound \\
\hline \multicolumn{9}{|l|}{ Alkanes } \\
\hline Pristane/phytane & 0.6 & 0.4 & 1.0 & 0.6 & 2.0 & 0.7 & 1.4 & 0.6 \\
\hline Pristane/n-C17 & 0.7 & 0.3 & 0.6 & 0.3 & 1.1 & 0.4 & 1.2 & 0.6 \\
\hline$n-\mathrm{C} 29 / n-\mathrm{C} 17$ & 1.5 & 3.5 & 9.6 & 5.8 & 5.7 & 2.1 & 10.0 & 7.5 \\
\hline Odd/even 1 & 2.0 & 1.4 & 4.1 & 2.6 & 1.9 & 2.6 & 1.7 & 1.2 \\
\hline \multicolumn{9}{|l|}{ Alkanoic acids } \\
\hline$n-\mathrm{C} 26 / n-\mathrm{C} 16$ & 0.9 & 0.2 & 2.4 & 0.3 & 0.7 & 0.1 & - & - \\
\hline Even/odd ${ }^{2}$ & 4.2 & 4.1 & 5.1 & 4.6 & 5.8 & 6.5 & - & - \\
\hline \multicolumn{9}{|l|}{ Alcohols } \\
\hline$n-\mathrm{C}_{26} / n-\mathrm{C} 16$ & 1.9 & 1.1 & 4.8 & 1.3 & 1.9 & 1.1 & - & - \\
\hline Even/odd ${ }^{3}$ & 2.5 & 1.3 & 3.7 & 1.7 & 2.1 & 1.0 & - & - \\
\hline C29/C27 stenols & 0.8 & 0.6 & 1.6 & 1.0 & 1.9 & 1.2 & - & - \\
\hline
\end{tabular}

Note: Dashes-not analyzed.

1 Over range of $\mathrm{C} 17$ to $\mathrm{C} 32$.

2 Over range of $\mathrm{C} 14$ to $\mathrm{C} 31$.

3 Over range of $\mathrm{C} 15$ to $\mathrm{C} 28$-alkanols.

probably reflects their destruction during early diagenesis, because terrigenous $n$-alkanes are important constituents of the sediment lipids at many DSDP sites and show that land-plant components are transported to deep-ocean sediments.

\section{Alkanols and Stenols}

Distributions of $n$-alkanols from Pleistocene samples from Holes 530B and 532 are shown in Figure 4. The free $n$-alkanols are dominated by $n$-C22, $n-\mathrm{C} 26$ and have obvious even-carbon-number predominances (Table 2). Bound alcohol fractions in general have weaker even-carbon-number predominances and contain relatively smaller contributions of long-chain alkanols.

Alkanols extracted from Quaternary sediments from other DSDP sites either under or near to areas of high marine productivity, and hence containing relatively high amounts of organic carbon, have distributions simlar to those found at these two Leg 75 sites. Some of these other locations include Site 362 (Boon et al., 1978), Site 440 (Brassell et al., 1980), and Sites 487 and 491 (Brassell et al., 1981). The presence of the longchain $n$-alkanols in DSDP sediments has been interpreted as indicating terrigenous inputs (Brassell et al., 1981 ) and is consistent with the important contributions of terrigenous $n$-alkanes and $n$-alkanoic acids in the samples from Holes 530B and 532 (Figs. 2 and 3). Such relatively large amounts of land-derived lipids in sediments found under areas of high production of marine organic matter may result from enhanced preservation of all types of organic materials. Further evidence of good preservation is indicated by the presence of unsat-
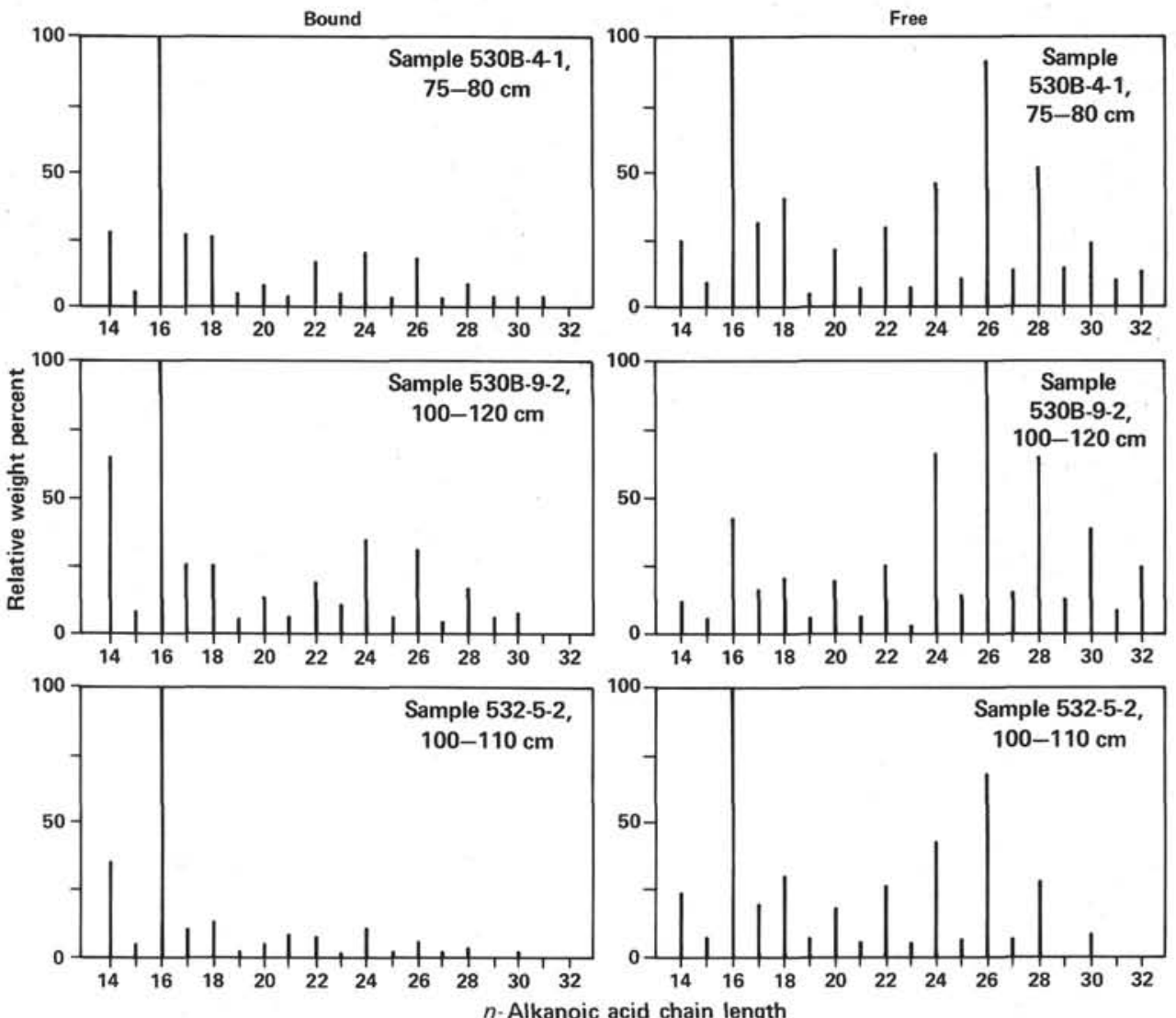

Figure 3. Histograms of free (right) and bound (left) $n$-alkanoic acids of Pleistocene diatomaceous clays. Distributions are normalized to their major component $(100 \%)$. 

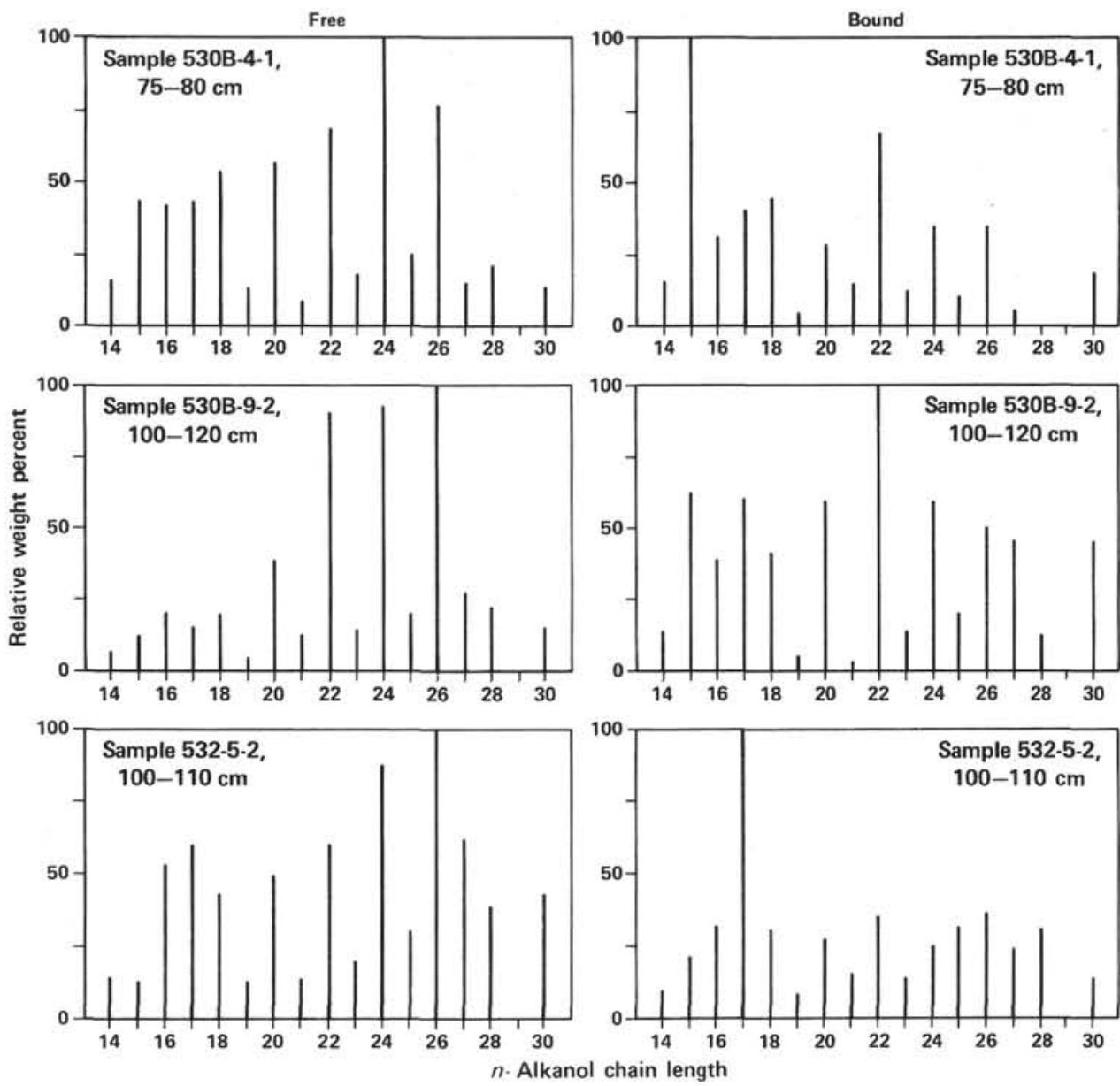

Figure 4. Histograms of free (left) and bound (right) $n$-alkanols of Pleistocene diatomaceous clays. Distributions are normalized to their major component $(100 \%)$.

urated alcohols, stenols, in the Pleistocene samples. Ratios of land-derived $\mathrm{C} 29$ stenols to marine-derived $\mathrm{C} 27$ stenols (Huang and Meinschein, 1976) agree with other source indicators in showing important terrigenous inputs (Table 2).

\section{Comparison of Samples}

Pleistocene sediments from Hole 530B in the Angola Basin contain similar amounts of organic matter and have similar distributions of lipid source indicators as compared to the Pleistocene sample from Hole 532 on the Walvis Ridge. These organic matter characteristics appear to be common to Quaternary sediments found under ocean margin areas having high surface productivity and hence are not positive proof of a common origin for the Quarternary sediments at these Leg 75 locations. The similarities in organic character, however, agree with other similarities in fossil content and sedimentology. This overall agreement strongly suggests that sediments from Hole 530B and from Hole 532 originated from similar depositional environments and that the Angola Basin sediments have undergone downslope relocation from areas on the Walvis Ridge. Such relocation is indicated by evidence of debris flows in the hydraulic-piston-cored Hole 530B sediments and by the relatively high concentrations of organic carbon in these sediments, suggesting that deposition was originally at shallower depths (cf. Suess, 1980).

\section{CONCLUSIONS}

1. Samples of Pleistocene and late Miocene sediment from Hole 530B in the Angola Basin and Hole 532 on the Walvis Ridge have geolipid distributions of mixed marine and terrigenous character. In general, land-plant components provide larger contributions to distributions of $n$-alkanes, $n$-alkanoic acids, and $n$-alkanols than do algal or bacterial components.

2. Geolipid distributions give evidence of relatively good preservation of organic matter.

3. Eolian input of continental materials to these oceanic sediments is inferred from important amounts of land-plant components in the geolipid distributions.

4. Strong similarities in the organic character of the sediments from these two locations suggest a common depositional environment, probably on the Walvis Ridge. Sediments at Site 530 in the Angola Basin have undergone relocation to their present position from their initial sites of deposition at shallower depths.

\section{ACKNOWLEDGMENTS}

We thank M. J. Leenheer, J. G. Quinn, and E. S. Van Vleet for reviewing this chapter and for suggesting ways to improve it. We are 
grateful to the Deep Sea Drilling Project/International Phase of Ocean Drilling for providing the opportunity for P. A. M. to participate in Leg 75.

\section{REFERENCES}

Boon, J. J., and deLeeuw, J. W., 1979. The analysis of wax esters, very long mid-chain ketones, and sterol ethers isolated from Walvis Bay diatomaceous ooze. Mar. Chem., 7:117-132.

Boon, J. J., van der Meer, F. W., Schuyl, P. J. W., de Leeuw, J. W., Schenck, P. A., and Burlingame, A. L., 1978. Organic geochemical analyses of core samples from Site 362, Walvis Ridge, DSDP Leg 40. In Bolli, H. M., Ryan, W. B. F., et al., Init. Repts. DSDP, Suppl. to Vols. 38, 39, 40, and 41: Washington (U. S. Govt. Printing Office), 627-637.

Brassell, S. C., Comet, P. A., Eglinton, G., Isaacson, P. J., McEvoy, J., Maxwell, J. R., Thomson, I. D., Tibbets, P. J. C., and Volkman, J. K., 1980. Preliminary lipid analyses of Sections 440A7-6, 440B-3-5, 440B-8-4, 440B-68-2, and 436-11-4: Legs 56 and 57, Deep Sea Drilling Project. In Scientific Party, Init. Repts. DSDP, 56, 57, Pt 2: Washington (U. S. Govt. Printing Office), 1367-1390.

Brassell, S. C., Eglinton, G., and Maxwell, J. R., 1982. Preliminary lipid analyses of two Quaternary sediments from the Middle America Trench, southern Mexico transect, Deep Sea Drilling Project Leg 66. In Watkins, J. S., Moore, J. C. et al., Init. Repts. $D S D P, 66:$ Washington (U. S. Govt. Printing Office), 557-580.

Degens, E. T., and Mopper, K., 1976. Factors controlling the distribution and early diagenesis of organic material in marine sediments. In Riley, J. P., and Chester, R. (Eds.), Chemical Oceanography (Vol. 6): New York (Academic Press), 59-113.

Didyk, B. M., Simoneit, B. R. T., Brassell, S. C., and Eglinton, G., 1978. Organic geochemical indicators of paleoenvironmental conditions of sedimentation. Nature, 272:216-222.

Diester-Haas, L., 1978. Sediments as indicators of upwelling. In Boje, R., and Tomczak, M. (Eds.), Upwelling Ecosystems: Berlin (SpringerVerlag), pp. 261-281.

Diester-Haass, L., and Schrader, H. J., 1979. Neogene coastal upwelling history off northwest and southwest Africa. Mar. Geol., 29:39-53.

Doran, T., and Johnson, P. G., 1979. Examination of potential geochemical contaminants in Leg 48 material. In Montadert, L., Roberts D. G., et al., Init. Repts. DSDP, 48: Washington (U. S. Govt. Printing Office), 1157-1160.

Erdman, J. G., and Schorno, K. S., 1978. Geochemistry of carbon: Deep Sea Drilling Project Leg 40. In Bolli, H. M., Ryan, W. B. F. et al., Init. Repts. DSDP, Suppl. to Vols. $38,39,40$, and 41 : Washington (U. S. Govt. Printing Office), 651-658.

Hay, W. W., Sibuet, J. C., and Shipboard Scientific Party, 1982. Sedimentation and accumulation of organic carbon in the Angola Basin and on the Walvis Ridge: Preliminary results of Deep Sea Drilling Project Leg 75. Geol. Soc. Am. Bull., 93:1038-1050.

Huang, W. Y., and Meinschein, W. G., 1976. Sterols as source indicators of organic materials in sediments. Geochim. Cosmochim. Ac$t a, 40: 323-330$.
McEvoy, J., Eglinton, G., and Maxwell, J. R., 1981. Preliminary lipid analyses of sediments from Sections $467-3-3$ and 467-97-2. In Yeats, R. S., Haq, B. U., et al., Init. Repts. DSDP, 63: Washington (U. S. Govt. Printing Office), 763-774.

Meyers, P. A., and Dunham, K. W., in press. Organic geochemistry of Quaternary sediments from Deep Sea Drilling Project Leg 72, South Atlantic Ocean. In Barker, P. F., Carlson, R. L., Johnson, D. A., et al., Init. Repts. DSDP, 72: Washington (U. S. Govt. Printing Office).

Meyers, P. A., and Keswani, S. R., in press. Organic geochemistry of Neogene Walvis Ridge sediments from Deep Sea Drilling Project Leg 74. In Moore, T. C., Jr., Rabinowitz, P. D., et al., Init. Repts. DSDP, 74: Washington (U. S. Govt. Printing Office).

Müller, P. J., 1977, C/N ratios in Pacific deep-sea sediments: Effect of inorganic ammonium and organic nitrogen compounds sorbed by clays. Geochim, Cosmochim. Acta, 41:765-776.

Rullkötter, J., Cornford, C., Flekken, P., and Welte, D. H., 1980a. Organic geochemistry of sediments cored during Deep Sea Drilling Project Legs 56 and 57, Japan Trench: Organic petrography and extractable hydrocarbons. In Scientific Party, Init. Repts. DSDP, 56, 57, Pt. 2: Washington (U. S. Govt. Printing Office), 1291-1304.

Rullkötter, J., Flekken, P., and Welte, D. H., 1980b. Organic petrography and extractable hydrocarbons of sediments from the northern Phillippine Sea. Deep Sea Drilling Project Leg 58. In Klein, G. deV., Kobayashi, K., et al., Init. Repts. DSDP, 58: Washington (U.S. Govt. Printing Office), 755-762.

Rullkötter, J., von der Dick, H., Welte, D. H., 1981. Organic petrography and extractable hydrocarbons of sediments from the eastern North Pacific Ocean, Deep Sea Drilling Project Leg 63. In Yeats, R. S., Haq, B. E. et al., Int. Repts. DSDP, 63: Washington (U. S. Govt. Printing Office), 819-836.

Siesser, W. G., 1980. Late Miocene origin of the Benguela upwelling system off northern Namibia. Science, 208:283-285.

Simoneit, B. R. T., 1977. Organic matter in eolian dusts over the Atlantic Ocean. Mar. Chem., 5:443-464.

, 1978a. The organic geochemistry of marine sediments. In Riley, J. P., and Chester, R. (Eds.), Chemical Oceanography (Vol. 7): London (Academic Press), 233-311.

1978b. Lipid analyses of sediments from Site 364 in the Angola Basin, DSDP Leg 40. In Bolli, H. M., Ryan, W. B. F., et al., Init. Repts. DSDP, Suppl. to Vols. 38, 39, 40, and 41: Washington (U. S. Govt. Printing Office), 659-662.

Simoneit, B. R. T., and Mazurek, M. A., 1981. Organic geochemistry of sediments from the southern California Borderland, Deep Sea Drilling Project Leg 63. In Yeats, R. S., Haq, B. U., et al., Init. Repts. DSDP, 63: Washington (U. S. Govt. Printing Office), 837-853.

Suess, E., 1980. Particulate organic carbon flux in the oceans-surface productivity and oxygen utilization. Nature, 288:260-263.

Waples, D. W., and Sloan, J. R., 1980. Carbon and nitrogen diagenesis in deep sea sediments. Geochim. Cosmochim. Acta, 44: 1463-1470.

Date of Initial Receipt: January 18, 1983 